\title{
Activity-Based Sensing with a Metal-Directed Acyl Imidazole Strat-egy Reveals Cell Type-Dependent Pools of Labile Brain Copper
}

\author{
Sumin Lee, ${ }^{1}$ Clive Yik-Sham Chung, ${ }^{1,6,7}$ Pei Liu, ${ }^{1}$ Laura Craciun, ${ }^{2}$ Yuki Nishikawa, ${ }^{4,5}$ Kevin J. Bruemmer, ${ }^{1}$ \\ Itaru Hamachi, ${ }^{4,5}$ Kaoru Saijo, ${ }^{2,3}$ Evan W. Miller, ${ }^{1,2,3}$ and Christopher J. Chang ${ }^{\star 1,2,3}$ \\ Departments of ${ }^{1}$ Chemistry, ${ }^{2}$ Molecular and Cell Biology, and ${ }^{3}$ Helen Wills Neuroscience Institute, University of California, Berkeley, \\ California 94720, United States \\ ${ }^{4}$ Department of Synthetic Chemistry and Biological Chemistry, Graduate School of Engineering, Kyoto University, Katsura, Nishikyo- \\ ku, Kyoto 615-8510, Japan \\ ${ }^{5}$ ERATO Innovative Molecular Technology for Neuroscience Project, Japan Science and Technology Agency (JST), Kyoto, 615-8530, \\ Japan \\ ${ }^{6}$ School of Biomedical Sciences and ${ }^{7}$ Department of Pathology, The University of Hong Kong, Hong Kong, P.R. China
}

\begin{abstract}
Copper is a required nutrient for life and particularly important to the brain and central nervous system. Indeed, copper redox activity is essential to maintaining normal physiological responses spanning neural signaling to metabolism, but at the same time copper misregulation is associated with inflammation and neurodegeneration. As such, chemical probes that can track dynamic changes in copper with spatial resolution, especially in loosely-bound, labile forms, are valuable tools to identify and characterize its contributions to healthy and disease states. In this report, we present an activity-based sensing (ABS) strategy for copper detection in live cells that preserves spatial information by a copper-dependent bioconjugation reaction. Specifically, we designed copper-directed acyl imidazole (CD) dyes that operate through copper-mediated activation of acyl imidazole electrophiles for subsequent labeling of proximal proteins at sites of elevated labile copper to provide a permanent stain that resists washing and fixation. To showcase the utility of this new ABS platform, we sought to characterize labile copper pools in the three main cell types in the brain: neurons, astrocytes, and microglia. Exposure of each of these cell types to physiologically relevant stimuli shows distinct changes in labile copper pools. Neurons display translocation of labile copper from somatic cell bodies to peripheral processes upon activation, whereas astrocytes and microglia exhibit global decreases and increases in intracellular labile copper pools, respectively, after exposure to inflammatory stimuli. This work provides foundational information on cell type-dependent homeostasis of copper, an essential metal in the brain, as well as a starting point for the design of new activity-based probes for metals and other dynamic signaling and stress analytes in biology.
\end{abstract}

\section{INTRODUCTION}

Copper is an essential element for human health. ${ }^{1}$ Indeed, enzymes harness the potent redox activity of this metal nutrient to perform functions spanning energy generation, pigment synthesis, and epigenetic modifications. ${ }^{1-7}$ Owing to the high metabolic and signaling needs of the brain, copper is found in particularly high concentrations in this organ, ${ }^{8-12}$ where work from our laboratory showed that activation of neurons causes a marked redistribution of cellular copper to affect the excitability of cultured neurons ${ }^{13}$, with subsequent studies identifying that these labile copper pools regulate spontaneous activity of circuits in retinal tissue ${ }^{12}$ and sleep behavior in zebrafish models in vivo ${ }^{14}$. On the other hand, misregulation of copper homeostasis can lead to cellular malfunctions resulting from aberrant increases in reactive oxygen species (ROS) that can lead to oxidative damage to proteins, lipids, and DNA/RNA. ${ }^{15,16}$ Such stress responses contribute to diseases including cancer, ${ }^{17-19}$ neurodegenerative diseases such as Alzheimer's, Parkinson's, and Huntington's diseases, ${ }^{20-24}$ and genetic disorders such as Menkes and Wilson's diseases. ${ }^{25-27}$ These correlations are intriguing, but the underlying causal contributions of copper homeostasis to function and disease in the brain and central nervous system remain insufficiently understood. To this end, a number of chemical technologies have been developed to probe biological copper fluxes by molecular imaging, including fluorescent, ${ }^{11-14,18,28-47}$ and magnetic resonance imaging (MRI), ${ }^{48-56}$ and bioluminescent ${ }^{57}$ copper indicators. These reporters can achieve high selectivity and signal-to-noise responses for copper ion imaging from cellular to tissue to whole animal settings. Application of these reagents, in conjunction with 
Scheme 1. Synthesis of a) CD649 and b) CD433 c) Schematic cartoon showing the working principle of CD dyes for fluorescent labeling of proximal proteins at sites of elevated labile copper
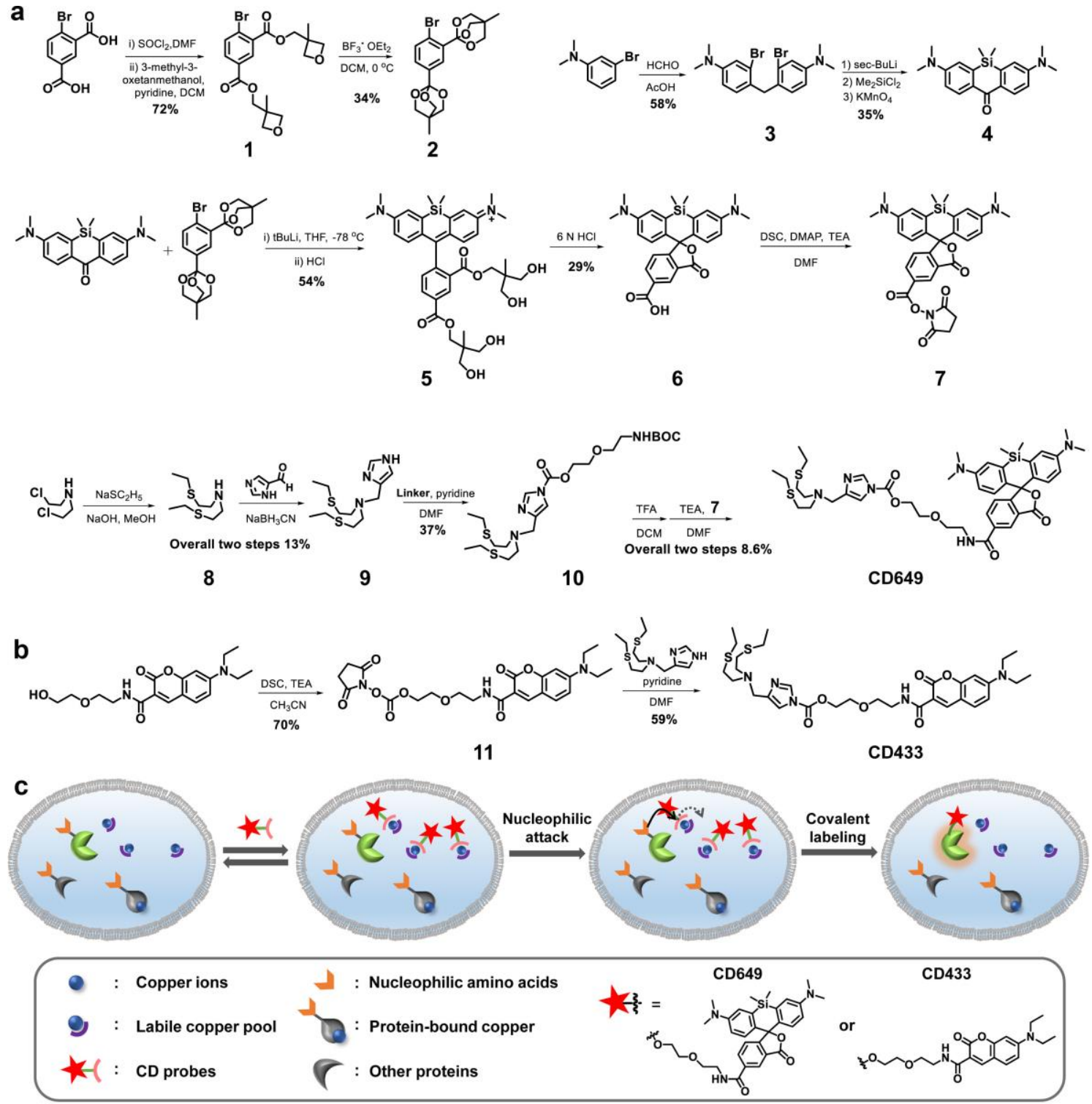

complementary biochemical, cellular, and animal studies, have given rise to the emerging concept of transition metal signaling, where such elements can reversibly modulate the activity of protein targets by fast and reversible binding beyond the active site. $4,17,58,59$

In this context, most fluorescent copper probes are designed to recognize labile copper ions based on thioether-rich receptors or tris[(2-pyridyl)methyl]amine (TPA) receptors ${ }^{40}$. These receptors have been exploited to trigger a fluorescent turn-on or ratiometric response by reversible coordination of copper ions or by activity-based sensing through irreversible uncaging of a fluorophore $40,60-63,18$ or luciferin. ${ }^{57}$ Despite advances in designing probes for studying copper biology, a gap in the field is to improve control over the localization of diffusible synthetic indicators to achieve higher spatial resolution for copper and related analytes of interest. To meet this need, we now present the design, synthesis and biological applications of a new type of activity-based sensing (ABS) platform ${ }^{64,65}$ for fluorescent copper detection using acyl imidazole bioconjugation chemistry. In ABS, the analyte is detected by an analyte-triggered reaction rather than a simple binding event, akin to activity-based protein profiling for reading out protein activity rather than protein abundance. We have prepared copper-directed acyl imidazole (CD) fluorescent probes that 


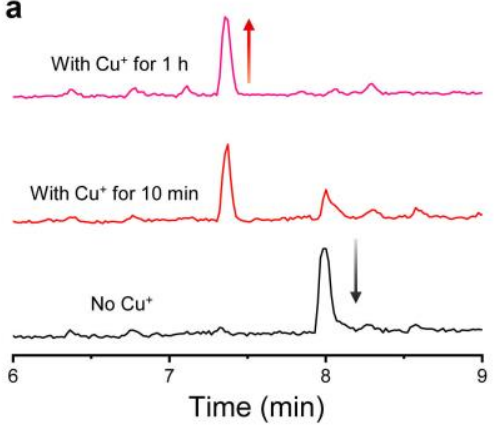

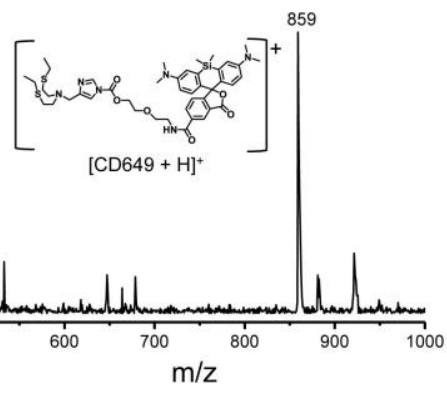

C

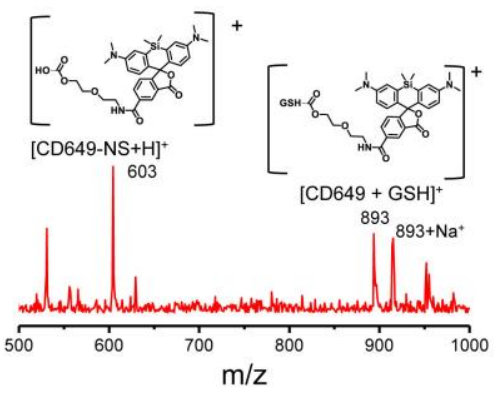

d
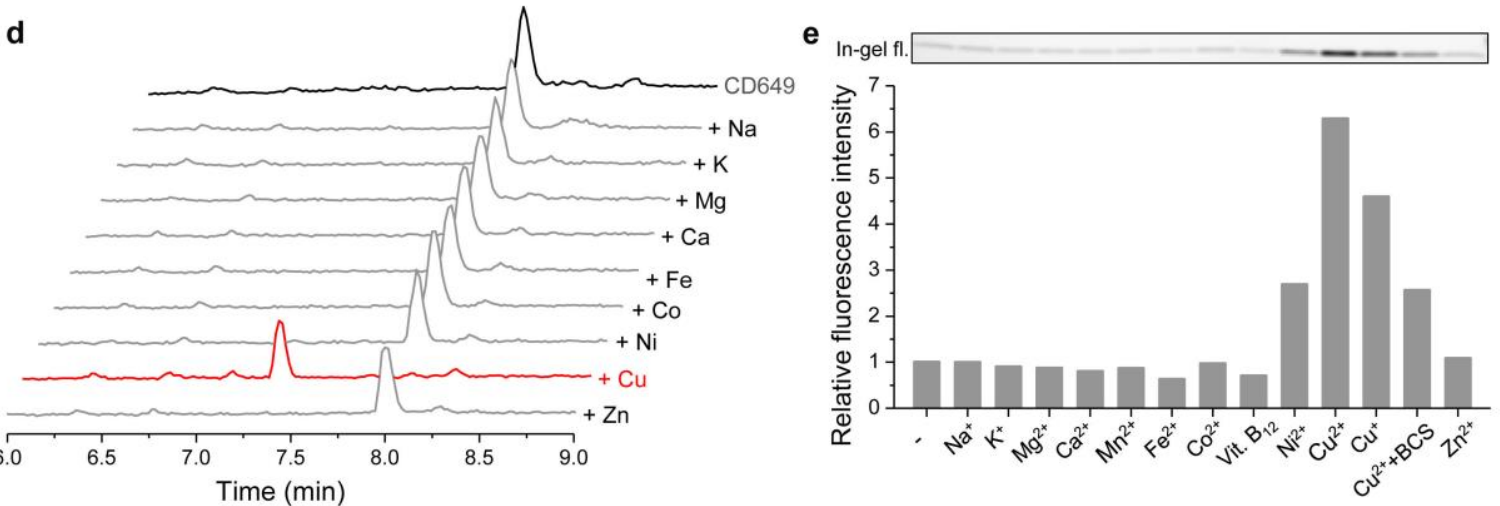

Figure 1. Copper reactivity and selectivity of CD probes in aqueous buffer solutions. a) LC chromatograms of the reaction between $5 \mu \mathrm{M}$ CD649 and $10 \mu \mathrm{M} \mathrm{Cu}(\mathrm{I})$ in PBS containing $25 \mu \mathrm{M}$ L-serine methyl ester and $2 \mathrm{mM}$ GSH for $1 \mathrm{~h}$, showing the complete conversion of CD649. b) The mass of intact CD649 probe was detected at a retention time of $8.0 \mathrm{~min}$ in the absence of $\mathrm{Cu}(\mathrm{I})$. c) The copper-responsive reaction products of $\mathrm{CD} 649 \mathrm{with} \mathrm{Cu}(\mathrm{I}) / 2$ $\mathrm{mM} \mathrm{GSH}$ are detected at a retention time of $7.4 \mathrm{~min}$. d) LC chromatograms of $5 \mu \mathrm{M}$ CD649 (top trace, black), $5 \mu \mathrm{M}$ CD649 incubated with $10 \mu \mathrm{M} \mathrm{Cu}(\mathrm{I})$ (red trace) for $30 \mathrm{~min}$, and other biologically relevant metals at $10 \mu \mathrm{M}\left(\mathrm{Na}^{+}, \mathrm{K}^{+}\right.$, $\mathrm{Mg}^{2+}, \mathrm{Ca}^{2+}, \mathrm{Fe}^{3+}, \mathrm{Co}^{2+}, \mathrm{Ni}^{2+}, \mathrm{Cu}^{+}$, and $\mathrm{Zn}^{2+}$, grey traces) for $30 \mathrm{~min}$ in PBS in the presence of $25 \mu \mathrm{M}$ L-serine methyl ester and $2 \mathrm{mM} \mathrm{GSH}$. The LC data support that CD649 shows high selective reactivity towards copper ions. e) Ingel fluorescence images and integrated fluorescence intensities of CD649 and lysozyme as a model protein for activity-based sensing of copper via copper-induced bioconjugation. Lysozyme was preincubated with biologically relevant metal ions for $5 \mathrm{~min}$ (s-block metal ions at $1 \mathrm{mM}$, d-block metal ions at $10 \mu \mathrm{M}, \mathrm{BCS}$ at $50 \mu \mathrm{M}$ ), followed by incubation with $1 \mu \mathrm{M}$ CD649 at room temperature for $2 \mathrm{~h}$. In-gel fluorescence for SDS-PAGE was scanned by ChemiDoc MP and signal intensity was analyzed by ImageJ.

feature a thioether NS2 receptor ${ }^{32,36,30,33}$ bearing a fused acyl imidazole linked to coumarin (CD433) or Sirhodamine (CD649) fluorophores, where copper binding increases the electrophilicity of the acyl imidazole unit for nucleophilic attack and covalent labeling of proximal proteins with the fluorescent dye. This approach is inspired by ligand-directed acyl imidazole (LDAI) reagents for proteomics and activity-based protein profiling (ABPP). ${ }^{66-72}$ One of the advantages of utilizing this LDAI strategy for sensing and imaging purposes is to overcome a major challenge that small-molecule fluorescent probes can diffuse away from their target upon binding. CD probes address this problem by leveraging the direct coordination of Lewis acidic copper ions, resulting in covalent bond formation between fluorescent reporters and proximal proteins in the cell to preserve spatial information of localized copper hotspots by minimizing diffusion of the dye away from the site of the ABS reaction. A second advantage is unlike existing activity-based sensing systems derived from TPA that require both $\mathrm{Cu}(\mathrm{I})$ and $\mathrm{O}_{2}$ to trigger a signal change, the $\mathrm{CD}$ probes can be activated directly by copper ions alone. The red-emissive CD probe CD649 was utilized to image increases and decreases in labile copper pools in live cells with exogenous copper supplementation or depletion, respectively, as well as monitor differences in labile copper status in genetic modified MEF cells with knockout of the ATP7A copper-exporter P-type ATPase compared to the wildtype congeners.

Moreover, to decipher fundamental copper biology in the central nervous system, CD649 was applied to characterize labile copper pools in the three major types of cells in the brain: neurons, astrocytes, and microglia. In primary cultured hippocampal neurons, CD649 revealed the translocation of labile copper from 
somatic cell bodies to the dendrites during neuronal depolarization. In parallel, CD649 identified global increases in labile copper in microglia and decreases in astrocytes during the inflammatory response. Taken together, this work provides a unique approach to direct activity-based sensing of copper that can retain spatial information with a modular design concept that applied to other biological analytes of interest. In addition, the foundational information on cell type-specific changes in labile copper offers a starting point for further investigations of copper biology in the brain and beyond to advance our understanding of transition metal signaling.

\section{RESULTS AND DISCUSSION}

Synthesis and Characterization of Copper-Directed Acyl Imidazole (CD) Probes for Activity-Based Sensing of Copper. To develop a copper-responsive activity-based sensing probe that operates by proximal protein labeling, a thioether NS2 motif fused to imidazole was chosen as the copper recognition unit as inspired by previous copper-selective fluorescent $4,11-13,28-32,41-43,58,73-77$ and MRI probes ${ }^{48,51-53}$ as well as porous polymers for copper capture and detection. ${ }^{78}$ The tripodal receptor 9 was synthesized in three steps. Dicarboxylic acid silicon-rhodamine 6 and its NHS ester 7 was prepared according to a reported procedure, ${ }^{79}$ and NHS ester $\mathbf{7}$ was amide coupled to compound $\mathbf{1 0}$ to give copper-directed acyl imidazole 649 (CD649, Scheme 1). The coumarin derivative 11 was synthesized following published literature protocols $^{66}$ and conjugated to compound 9 to give CD433 (Scheme 1). The final CD probes were characterized by ${ }^{1} \mathrm{H}$ and ${ }^{13} \mathrm{C}\left\{{ }^{1} \mathrm{H}\right\} \mathrm{NMR}$, LC-MS, and high-resolution MS.

For labeling proximal proteins in live cells in a copper-dependent manner, the CD probes should bind and react through accessible nucleophilic amino acids. To evaluate the reactivity and stability of the CD probes in vitro, the hydrolysis reaction of CD433 in the presence or absence of $\mathrm{Cu}(\mathrm{I})$ was monitored by liquidchromatography in PBS buffer containing glutathione (2 mM). CD433 alone is stable in aqueous solutions as monitored for $4 \mathrm{~h}$, but the introduction of copper promotes rapid reactivity at the carbamate unit of the
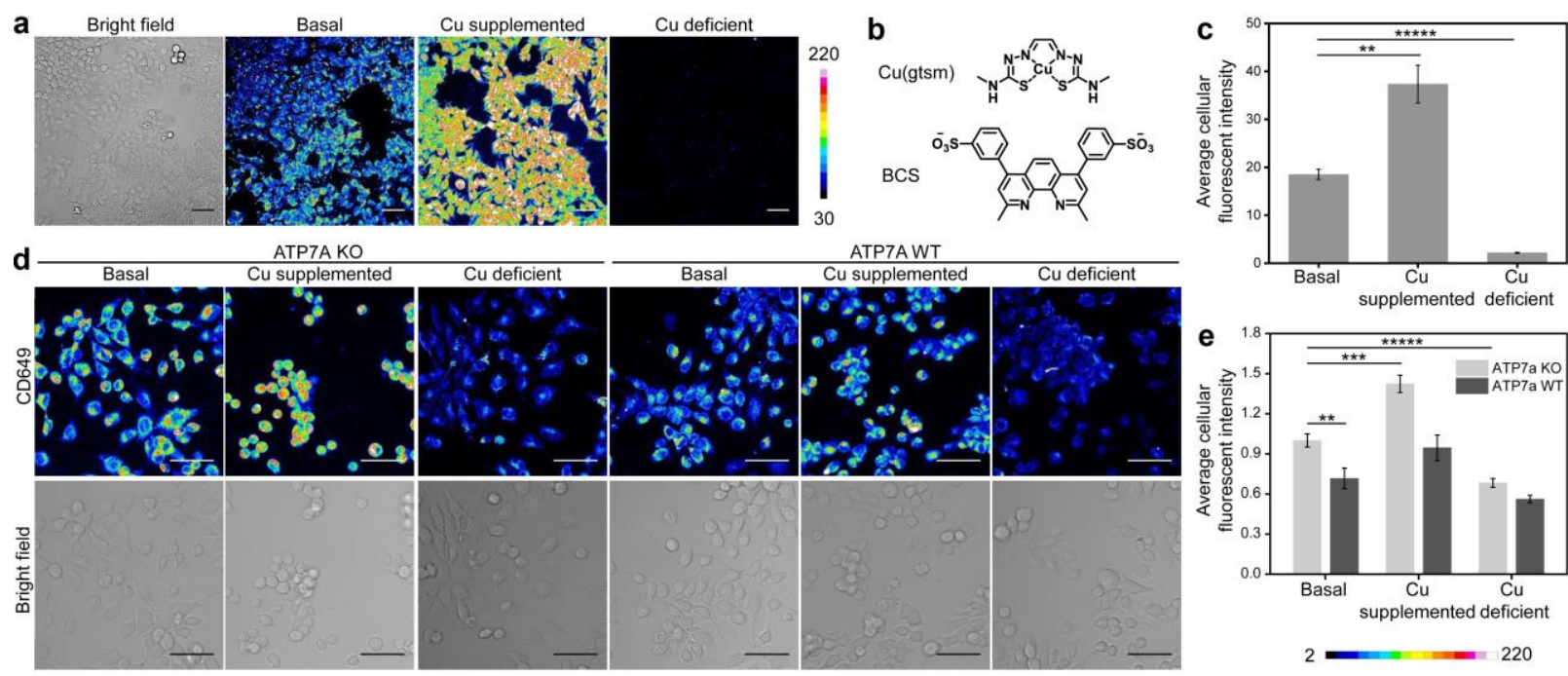

Figure 2. Fluorescence imaging of labile copper pools in live HEK293T cells and MEF cells with wildtype or altered expression levels of the copper transporter protein ATP7A using CD649. a) Confocal fluorescence microscopic images of HEK 293T cells treated with $1 \mu \mathrm{M}$ CD649 alone, CD649 and $2 \mu \mathrm{M} \mathrm{Cu}(\mathrm{gtsm})$ for $\mathrm{Cu}$ supplementation, or CD649 and $200 \mu \mathrm{M}$ BCS for Cu deficiency. The cells were incubated with $2 \mu \mathrm{M} \mathrm{Cu}(\mathrm{gtsm})$ for 2 hrs or $200 \mu \mathrm{M}$ BCS in DMEM/10\% FBS medium overnight and washed with DMEM/10\% FBS and PBS, followed by incubation with $1 \mu \mathrm{M}$ CD649 in DPBS solution and then imaged after $15 \mathrm{~min}$. b) Chemical structures of $\mathrm{Cu}(\mathrm{gtsm})$ and BCS. c) Normalized cellular fluorescence intensities of the HEK 293T cells as determined using ImageJ, showing a turn on response when treated with $\mathrm{Cu}(\mathrm{gtsm})$ and a turn-off response in the presence of BCS. Error bars denote standard derivation (SD; $n=3$ ). Scale bar $=50 \mu \mathrm{m}$. d) Confocal fluorescence microscopic images of MEF ATP7A WT or $\mathrm{KO}$ cells treated with DMSO vehicle, $2 \mu \mathrm{M} \mathrm{Cu}(\mathrm{gtsm})$ for $30 \mathrm{~min}$, or $200 \mu \mathrm{M}$ BCS for overnight in DMEM $10 \%$ FBS and washed with DMEM/10\% FBS and PBS, followed by incubation with $1 \mu \mathrm{M}$ CD649 in DPBS and then imaged after 15 min. e) Average cellular fluorescence intensity of CD649 determined from experiments performed in triplicate with $\lambda_{\mathrm{ex}}=633 \mathrm{~nm}$. Error bars denote standard derivation (SD; $\mathrm{n}=3$ ). Scale bar $=50 \mu \mathrm{m} .{ }^{*} \mathrm{p}<0.05,{ }^{* *} \mathrm{p}<0.01,{ }^{* * *} \mathrm{p}<0.001$, and ${ }^{* * * *} \mathrm{p}<0.0001$. 
acyl imidazole and hydrolysis with a 7.1-fold increase in product formation as found in LC chromatogram (Figure S1). Likewise, liquid chromatograms of the reaction between $5 \mu \mathrm{M} C D 649$ and 2 equiv of $\mathrm{Cu}(\mathrm{I})$ in PBS in the presence of 5 molar equiv of L-serine methyl ester and $2 \mathrm{mM}$ glutathione (GSH) showed complete conversion to the copper-bound species and/or the copper-induced acyl transfer reaction product within $1 \mathrm{~h}$ (Figure 1a).

After $30 \mathrm{~min}$, the intact CD649 probe disappeared to afford a product with a mass of $603 \mathrm{~m} / \mathrm{z}$ (Figure 1b), corresponding to the cleaved CD649 species with loss of the copper receptor and another product with a mass of $893 \mathrm{~m} / \mathrm{z}$ that corresponds to CD649 coupled to GSH, with a retention time at $7.4 \mathrm{~min}$. (Figure 1c). Control experiments performed in the absence of amino acids revealed that CD649 does indeed fragment upon addition of copper ions; however, the resulting products were not detected at the retention time of 7.4 min, supporting the idea that nucleophilic amino acids are necessary to generate the copper-responsive reaction products (Figure S3). This activity-based sensing reaction is copper-selective, which is supported by liquid chromatography trace of $C D$ probes incubated with other biologically relevant metal ions. Indeed, comparing the LC traces of CD649 with $10 \mu \mathrm{M} \mathrm{Na}^{+}, \mathrm{K}^{+}, \mathrm{Mg}^{2+}, \mathrm{Ca}^{2+}, \mathrm{Fe}^{3+}, \mathrm{Co}^{2+}, \mathrm{Ni}^{2+}, \mathrm{Cu}^{+}$, or $\mathrm{Zn}^{2+}$ with Lserine methyl ester $(25 \mu \mathrm{M})$ and $2 \mathrm{mM} \mathrm{GSH}$ in PBS, CD649 showed the conversion to 7.4 min retention time products only with copper addition (Figure 1d). After the metal selectivity was evaluated in aqueous conditions, we proceeded to test the copper-directed labeling strategy with lysozyme as a model protein owing to its commercial availability in large quantities (Figure 1e, Figure S4). Lysozyme $(1.55 \mu \mathrm{M}, 50 \mu \mathrm{L}$ ) was incubated with biologically relevant metal ions for $30 \mathrm{~min}$ at room temperature and then the premixed solutions were further incubation with $1 \mu \mathrm{M}$ of CD649 for 30 min. Fluorescent gel analysis showed that CD649 selectively labels the protein in case of $\mathrm{Cu}(\mathrm{I}) / \mathrm{Cu}(\mathrm{II})$ and the labeled band became significantly diminished upon addition of BCS (structure is shown at Figure 2b), supporting the notion that the nucleophilic amino acids on a protein surface were labeled with CD649 via acyl transfer reaction in the presence of copper ions (Figure 1e). To investigate any oxidation state specificity of CD probes toward copper, lysozyme in PBS was premixed with $\mathrm{Cu}(\mathrm{I}) / \mathrm{Cu}(\mathrm{II})$ for $5 \mathrm{~min}$, followed by incubation with $\mathrm{CD} 649$ for $2 \mathrm{~h}$ under a N2 atmosphere so that no oxidation of $\mathrm{Cu}(\mathrm{I})$ would occur. Similar fluorescence intensities of labeled lysozyme were found in the presence of $\mathrm{Cu}(\mathrm{I})$ and $\mathrm{Cu}(\mathrm{II})$ ions respectively (Figure S10), indicating that the $\mathrm{CD}$ probes are responsive toward both $\mathrm{Cu}(\mathrm{I})$ and $\mathrm{Cu}(\mathrm{II})$ ions.

In addition, we found a linear increase in fluorescence intensity of HEK 293T cell lysates labeled by CD649 with increasing copper ion concentration, and a limit of detection is found to be $0.864 \mathrm{nM}$ (Figure S8). These data suggest that protein labeling by the CD probes is highly sensitive and dose-dependent

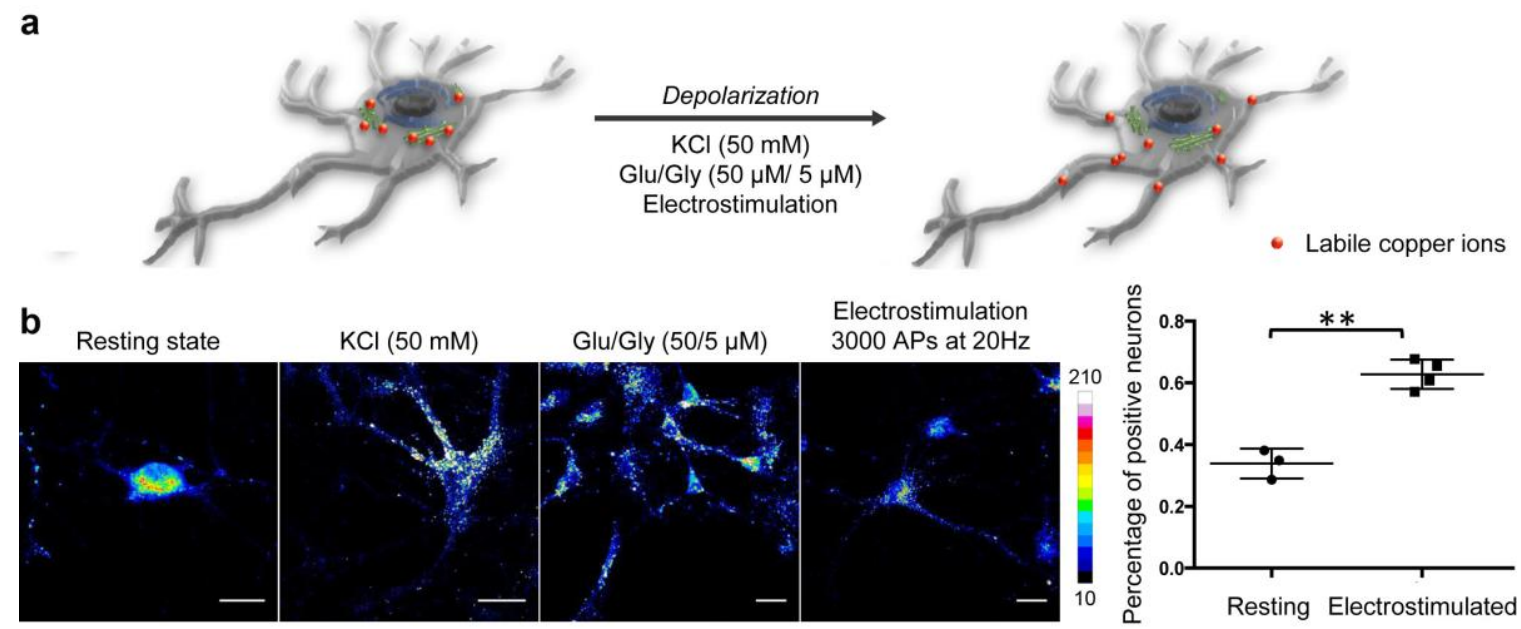

Figure 3. CD649 can image translocation of labile copper pools from cell bodies to projections in cultured primary neurons upon electrical stimulation. a) Depiction of observed copper redistributions in neurons before and after depolarization by various stimuli. b) Fluorescence images of primary cultured hippocampal neurons stained with $1 \mu \mathrm{M} \mathrm{CD} 649$ in the resting state and after depolarization by $\mathrm{KCl}(50 \mathrm{mM}), 50 \mu \mathrm{M}$ glutamate and $5 \mu \mathrm{M}$ glycine (Glu/Gly), or electrostimulation (3000 evoked action potentials at a frequency of $20 \mathrm{~Hz}$ ). c) Percentage of neurons showing copper pools residing at distances greater than one cell body away from soma. The percentage of such neurons increases significantly after depolarization. Scale bar is $20 \mu \mathrm{m}$. ${ }^{* *} p<0.01$. 
ASTROCYTES

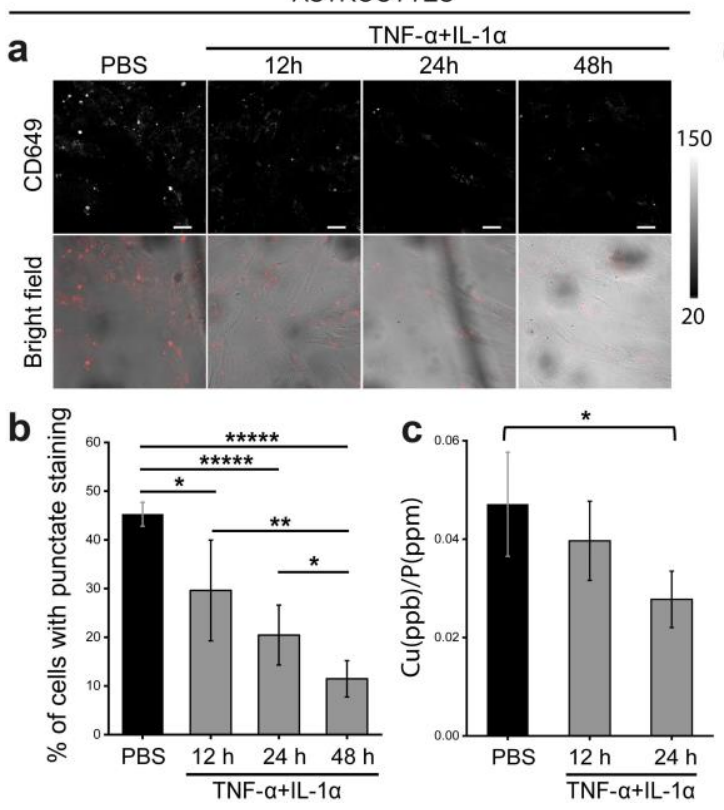

MICROGLIA
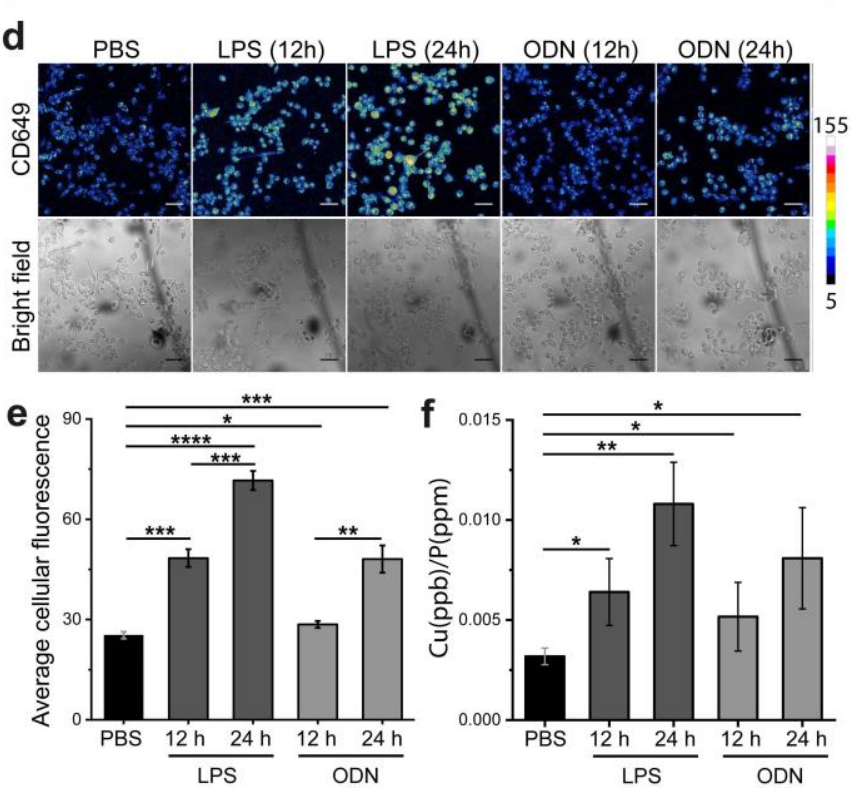

Figure 4. Fluorescence imaging of labile copper pools in human astrocytes (HA) and microglia SIMA9 under various inflammatory responses using CD649. a) Confocal fluorescence microscopic images of astrocytes treated by PBS control or a combination of TNF- $\alpha$ and IL-1 $\alpha$ (both at $20 \mathrm{ng} / \mathrm{mL}$ ) up to 48 hours and stained with 5 $\mu \mathrm{M}$ CD649 in HBSS for $30 \mathrm{~min}$, fixed and then imaged. Scale bar $=25 \mu \mathrm{m}$. b) Average cellular fluorescence intensity of CD649 determined from experiments in a) performed in triplicate with $\lambda_{\mathrm{ex}}=633 \mathrm{~nm}$. Error bars denote standard deviation (SD; $n=3$ ) c) ICP-MS measurement to determine total cellular ${ }^{63} \mathrm{Cu}$ levels in astrocytes under TNF- $\alpha$ and IL-1 $\alpha$ inflammatory stimuli (with normalization of different cell numbers by total cellular ${ }^{31} \mathrm{P}$ level). Error bars denote $\mathrm{SD} ; \mathrm{n}=2$. d) Confocal fluorescence microscopic images of microglia stimulated by PBS control, lipopolysaccharide (LPS, $0.1 \mu \mathrm{g} / \mathrm{mL}$ ), or $\mathrm{CpG}$ oligodeoxynucleotides (ODN, $5 \mu \mathrm{g} / \mathrm{mL}$ ). $5 \mu \mathrm{M}$ CD649 in HBSS was incubated subsequently for 30 minutes and then imaged after fixation. Scale bar $=25 \mu \mathrm{m}$. e) Average cellular fluorescence intensity of CD649 determined from experiments in d) performed in triplicate with $\lambda_{\mathrm{ex}}=633 \mathrm{~nm}$. Error bars denote SD; $n=5$ different images from the triplicate experiments. f) ICP-MS measurement to determine total cellular ${ }^{63} \mathrm{Cu}$ levels in microglia under various inflammatory stimuli (with normalization of different cell numbers by total cellular ${ }^{31} \mathrm{P}$ level). Error bars denote standard derivation (SD; $\mathrm{n}=2$ ). ${ }^{*} \mathrm{p}<0.05,{ }^{* *} \mathrm{p}<0.01,{ }^{* \star *} \mathrm{p}<0.001$, and ${ }^{* \star * *} \mathrm{p}<0.0001$.

toward copper. A dose-dependent increase in fluorescence intensity of lysozyme labeled by CD649 was also found with increasing copper, whereas changes in fluorescence intensities with fixed copper ion concentrations and varying lysozyme concentrations were much smaller and plateaued at high lysozyme concentrations (Figure S9). In view of the much higher concentrations of protein compared to CD probe in biological environments, the effect of changes in protein concentration on observed fluorescence should be minimal. Finally, to evaluate the relative copper affinity of the CD probes, CD433 was employed in a competitive copper binding assay with the reported copper fluorescent probe, CSR1, whose emission profile does not overlap with that of CD433. 80,81 In these experiments, CD433 (0-5 equiv) was continuously added to a pH 7.0 buffer solution (25 mM HEPES) containing the copper-complexed form of CSR1, which is reported to have a dissociation constant $\left(K_{d}\right)$ with $\mathrm{Cu}(\mathrm{I})$ of $2 \times 10^{-13} \mathrm{M} .{ }^{59}$ The solution containing the probes was excited at $608 \mathrm{~nm}$, where CD433 does not absorb, and as the concentration of CD433 was increased, the observed fluorescence intensity derived from CSR1 significantly decreased, suggesting that CD433 can compete with CSR1 for copper binding and is capable of displacing the copper ion from this Sirhodol sensor (Figure S6). As CSR1 is capable of monitoring dynamic changes in labile copper pools in live cells as shown by identification of copper fluxes induced by lipolysis ${ }^{59}$, this set of experiments presages that the CD platform should have sufficient affinity for copper in related cellular assays.

Live-Cell Imaging of Labile Copper Pools with CD649 Under Situations of Copper Elevation or Depletion. After establishing that CD probes are sensitive to copper with high metal selectivity and can label a model protein by SDS-PAGE analysis with a fluorogenic readout, we next tested the ability of this 
ABS platform to respond to changes in labile copper levels in living cells. Specifically, we applied CD649 to live HEK293 cells and cellular copper levels were perturbed by pre-incubating with $\mathrm{Cu}(\mathrm{gtsm})$ to increase intracellular copper levels and BCS to decrease intracellular copper levels. As anticipated, we observed a robust 2 -fold increase in fluorescence intensity following treatment with $2 \mu \mathrm{M} \mathrm{Cu}(\mathrm{gtsm})$, with the labeling being distributed evenly across the cytosol as compared to the punctate staining pattern observed under basal conditions. In contrast, HEK 293T cells pretreated with $200 \mu \mathrm{M}$ BCS for $10 \mathrm{~h}$ to induce copper depletion displayed a significant decrease in fluorescence intensity as compared to control cells as shown with CD649 imaging (Figure 2a), establishing that this ABS probe can monitor changes in labile copper levels in live cells, with fairly low cell toxicity as indicated by PrestoBlue assay (Figure S11). Likewise, CD433 was incubated with HEK 293T cell lysates in the presence of 1 equiv of $\mathrm{Cu}(\mathrm{I})$, and fluorescent intensity was measured at different incubation times up to 120 min. Those experiments show that the integrated fluorescence linearly increased and the fluorescence was quenched by pre-incubation with BCS (Figure S7), which confirms the copper-responsiveness of this probe. Next, we sought to evaluate the ability of CD649 to assay labile copper pools in genetic models of copper misregulation. In particular, we focused on matched cell lines with different levels of ATP7A, a copper-translocating P-type ATPase that regulates cellular copper pools by mediating cellular copper egress and secretory function. Indeed, mutations in the copper transporters ATP7A and ATP7B are at the heart of genetic disorders of copper homeostasis. ${ }^{26,82-84}$ In particular, Menkes disease is derived from a loss of ATP7A function with systemic copper misregulation leads to hyperaccumulation of liver copper. ${ }^{85}$ As anticipated, CD649-stained ATP7A knockout (KO) cells showed significantly higher levels of fluorescence compared to control ATP7A wildtype (WT) cells, revealing that CD649 can indeed detect elevated levels of labile copper in ATP7A KO cells, presumably due to the deficiency in cellular copper export (Figure $2 \mathrm{~d}$ and e). Furthermore, both WT and KO cells showed an increase in fluorescence signal following incubation with $\mathrm{Cu}(\mathrm{gtsm})$ in a time- and dose-dependent manner, which can be attenuated by the addition of the copper chelator BCS (Figure 2b). These data validate that CD649 can detect changes in labile copper levels with pharmacological and/or genetic manipulation.

CD649 Enables Activity-Based Sensing of Copper in Major Brain Cell Types. After confirming that CD649 can monitor changes in labile copper pools in mammalian cell line models, we then moved on to apply this new chemical tool to probe labile copper pools relevant to the brain and central nervous system. Indeed, copper homeostasis has profound effects in the brain as a neuromodulator in healthy states ${ }^{12,14,86-}$ 89 and as a mediator of neuroinflammation and neurotoxicity in aging and disease states ${ }^{6,14,90-93}$. In this context, previous work from our laboratory using a combination of X-ray fluorescence microscopy (XRFM) and a reversible binding-based BODIPY fluorescent probe for copper (CS3) identified that neuronal activity triggers significant movements of labile copper pools from the soma to peripheral neuronal processes. ${ }^{13}$ Here, we sought to expand on this observation by providing foundational information on labile copper pools in three main types of cells in the brain for comparison: neurons, astrocytes, and microglia. Starting with neurons, CD649 revealed punctate staining localized primarily to the soma of cultured primary hippocampal neurons in their resting state (Figure 3b). Activation and depolarization of these cultures by $50 \mathrm{mM} \mathrm{KCl}$ for $2 \mathrm{~min},{ }^{13}$ or glutamate/glycine $(50 \mu \mathrm{M} / 5 \mu \mathrm{M}){ }^{8}$ or electrostimulated (3000 evoked action potentials at a frequency of $20 \mathrm{~Hz}$ ), ${ }^{94,95}$ followed by staining with $1 \mu \mathrm{M} \mathrm{CD649}$, showed a significant redistribution of labile copper pools from somatic cell bodies to peripheral locations, in agreement with previous XRFM/CS3 data. ${ }^{13}$ The percentage of CD649-stained neurons showing redistributed copper ions at least one cell body away from the center of the neuron was calculated, revealing that depolarized neurons have a 2-fold increase relative to resting neurons (Figure 3c), consistent with soma to dendrite copper pool redistribution. We also applied CD649 to real-time monitoring of labile copper pools in hippocampal neurons, showing punctate localization of labile copper in somatic cell bodies in neurons in their resting state with loss of these puncta upon application of a depolarization stimulus (Figure S12).

Next, we sought to characterize labile copper pools in astrocyte and microglia, as these cell types in the brain influence neurogenesis, angiogenesis, immune response, and synaptogenesis. ${ }^{96}$ In particular, astrocytes have been reported as key regulators of brain copper homeostasis as they can efficiently acquire, store, and export copper owing to their high resistance to copper toxicity. ${ }^{96,97}$ On the other hand, microglia are the major resident immune cells in the brain, producing factors that influence surrounding astrocytes and neurons and promoting neuron survival as well as synaptic pruning, ${ }^{97-99,96}$ with less known about their copper biology. As both of these cell types are involved in inflammation, we utilized CD649 to probe changes in labile copper pools in human astrocyte (HA) and microglia SIMA9 cell lines in response to inflammatory stimuli. Cells were pretreated with inflammatory activators such as tumor necrosis factor alpha 
(TNF- $\alpha$ ), interleukin-1 alpha (IL-1 $\alpha$ ), lipopolysaccharide (LPS), or CpG oligodeoxynucleotides (ODN), washed and then stained with $5 \mu \mathrm{M}$ CD649. CD649 revealed labile copper pools localized in a punctate pattern within human astrocytes in their resting state. Stimulation with TNF- $\alpha$ and IL-1 $\alpha$ triggers a loss of punctate staining over increased inflammatory response (Figure $4 a$ and $b$ ). The decrease in fluorescence signals measured by CD649 was supported by complementary ICP-MS measurements of total cellular copper to phosphorus ratios showing expected decreases in the response to TNF- $\alpha$ and IL-1 $\alpha$ inflammatory stimuli (Figure 4c), suggesting a reduction and/or relocalization of labile copper pools. In contrast, microglia SIMA9 cells showed an increase in their labile copper pools in the response to inflammatory stimuli such as LPS and ODN compared to their basal state as monitored by CD649 imaging (Figure 4d and e). The increases in labile copper-dependent fluorescence signals were also supported by complementary ICP-MS measurements of total cellular copper (Figure 4f). The observed increase in the microglial labile copper pool under inflammatory stimuli is in line with a previous study reporting increased expression of ATP7A of the microglia cells in the response to the pro-inflammatory response. ${ }^{100-102}$ The rise in ATP7A leads to increased copper uptake and elevated expression of the CTR1 copper importer to expand the overall labile copper pool. ${ }^{101}$ Taken together, these data showcase the utility of CD649 for activity-based sensing of copper applied to reveal basic information on labile copper pools and their distinct dynamics in various brain cell types.

\section{CONCLUDING REMARKS}

To close, we have described the design, synthesis, and characterization of a unique platform for activitybased sensing (ABS) of copper by exploiting copper-dependent bioconjugation chemistry of acyl imidazole electrophiles. CD probes respond in a copper-dependent manner by increased covalent labeling of the dye with proximal proteins in cells at sites with elevated labile copper pools, which minimizes dye diffusion away from copper hotspots and preserves spatial information. This ABS strategy utilizes direct copper binding to trigger a fluorogenic response and does not require a metal- and oxygen-dependent reaction, offering an advantage over previous TPA-derived ABS probes. CD649 is capable of imaging changes in labile copper pools in HEK 293T and MEF cells with pharmacological copper supplementation and depletion, as well as detect elevations in endogenous levels of labile copper accumulation caused by knockout of the ATP7A copper exporter in MEF cell models. Moreover, we applied CD649 to characterize labile copper pools in the three main cell types in the brain: neurons, astrocytes, and microglia. In cultured primary hippocampal neurons, CD649 can track redistributions of labile copper pools from somatic cell bodies to peripheral processes upon depolarization. This probe also reveals distinct cell-specific responses in labile copper dynamics with inflammatory stimuli, where inflammation triggers relocation of labile copper in astrocytes and a labile copper increase in microglia. We speculate that the opposing dynamics of labile copper in these two cell types may contribute to neuroinflammatory reactions, where labile copper contraction in astrocytes is compensated by labile copper expansion in microglia as signal to communicate between cell types. Such crosstalk could serve as a neuroprotective mechanism in neurodegenerative disease. Current efforts are geared toward expanding the palette of $A B S$ probes that operate by dual sensing/bioconjugation mechanisms for dual imaging/proteomics purposes, as well as applying CD649 and related chemical tools to decipher the biology of metals in the brain and beyond. We anticipate that such activity-based reagents will be of value in providing foundational information on the continuum between metal signaling and metal metabolism.

\section{ASSOCIATED CONTENT}

Supporting Information. Experimental details including synthesis and characterization, kinetic studies for copper and iron uptake, and regeneration. This material is available free of charge via the Internet at http://pubs.acs.org.

\section{AUTHOR INFORMATION}

Corresponding Authors

*E-mail: chrischang@berkeley.edu

\section{ORCID}


Sumin Lee 0000-0003-4179-7952

Clive Chung 0000-0003-1382-719X

Pei Liu 0000-0002-4667-1139

Kevin J. Bruemmer 0000-0003-3416-5615

Itaru Hamachi: 0000-0002-3327-3916

Kaoru Saijo 0000-0003-1656-1753

Evan W. Miller: 0000-0002-6556-7679

Christopher J. Chang: 0000-0001-5732-9497

\section{Author Contributions}

S.L, C.Y.-S.C. contributed equally to this work.

\section{Notes}

A patent application has been filed for this copper detection strategy.

\section{ACKNOWLEDGMENT}

We thank the NIH (GM 79465 to C.J.C. and R35 GM119855 to E.W.M.) for support of this work. C.Y.-S.C thanks the Croucher Foun-dation for a postdoctoral fellowship. P.L. was supported by a graduate fellowship from A*STAR, Singapore. K. S. thanks the NIH (1R01HD09203) and Pew Scholarship. We thank Alison Killilea, Carissa Tasto, and Molly Fischer of the UC Berkeley Cell Culture Facil-ity for cell culture support and thank Stefan Schmollinger at Sabeeha Merchant lab at UC Berkeley for ICP-MS measurement.

\section{REFERENCES}

(1) Lippard, S. J.; Berg, J. M. Principles of Bioinorganic Chemistry; University Science Books: Mill Valley, Calif., 1994.

(2) Davis, A. V.; O'Halloran, T. V. A Place for Thioether Chemistry in Cellular Copper lon Recognition and Trafficking. Nat. Chem. Biol. 2008, 4 (3), 148-151. https://doi.org/10.1038/nchembio0308-148.

(3) Boal, A. K.; Rosenzweig, A. C. Structural Biology of Copper Trafficking. Chem. Rev. 2009, 109 (10), 4760-4779. https://doi.org/10.1021/cr900104z.

(4) Chang, C. J. Searching for Harmony in Transition-Metal Signaling. Nat. Chem. Biol. 2015, 11 (10), 744-747. https://doi.org/10.1038/nchembio.1913.

(5) Guengerich, F. P. Introduction to Metals in Biology 2018: Copper Homeostasis and Utilization in Redox Enzymes. J. Biol. Chem. 2018, 293 (13), 4603-4605. https://doi.org/10.1074/jbc.TM118.002255.

(6) Ackerman, C. M.; Chang, C. J. Copper Signaling in the Brain and Beyond. J. Biol. Chem. 2018, 293 (13), 4628-4635. https://doi.org/10.1074/jbc.R117.000176.

(7) Hunsaker, E. W.; Franz, K. J. Emerging Opportunities To Manipulate Metal Trafficking for Therapeutic Benefit. Inorg. Chem. 2019, 58 (20), 13528-13545. https://doi.org/10.1021/acs.inorgchem.9b01029.

(8) Schlief, M. L. NMDA Receptor Activation Mediates Copper Homeostasis in Hippocampal Neurons. J. Neurosci. 2005, 25 (1), 239-246. https://doi.org/10.1523/JNEUROSCI.3699-04.2005.

(9) Gaggelli, E.; Kozlowski, H.; Valensin, D.; Valensin, G. Copper Homeostasis and Neurodegenerative Disorders (Alzheimer's, Prion, and Parkinson's Diseases and Amyotrophic Lateral Sclerosis). Chem. Rev. 2006, 106 (6), 1995-2044. https://doi.org/10.1021/cr040410w.

(10) Barnham, K. J.; Bush, A. I. Biological Metals and Metal-Targeting Compounds in Major Neurodegenerative Diseases. Chem. Soc. Rev. 2014, 43 (19), 6727-6749. https://doi.org/10.1039/C4CS00138A.

(11) Que, E. L.; Domaille, D. W.; Chang, C. J. Metals in Neurobiology: Probing Their Chemistry and Biology with Molecular Imaging. Chem. Rev. 2008, 108 (5), 1517-1549. https://doi.org/10.1021/cr078203u.

(12) Dodani, S. C.; Firl, A.; Chan, J.; Nam, C. I.; Aron, A. T.; Onak, C. S.; Ramos-Torres, K. M.; Paek, J.; Webster, C. M.; Feller, M. B.; Chang, C. J. Copper Is an Endogenous Modulator of Neural Circuit 
Spontaneous Activity. Proc. Natl. Acad. Sci. 2014, 111 (46), 16280-16285. https://doi.org/10.1073/pnas.1409796111.

Dodani, S. C.; Domaille, D. W.; Nam, C. I.; Miller, E. W.; Finney, L. A.; Vogt, S.; Chang, C. J. Calcium-Dependent Copper Redistributions in Neuronal Cells Revealed by a Fluorescent Copper Sensor and X-Ray Fluorescence Microscopy. Proc. Natl. Acad. Sci. 2011, 108 (15), 5980-5985. https://doi.org/10.1073/pnas.1009932108.

Xiao, T.; Ackerman, C. M.; Carroll, E. C.; Jia, S.; Hoagland, A.; Chan, J.; Thai, B.; Liu, C. S.; Isacoff, E. Y.; Chang, C. J. Copper Regulates Rest-Activity Cycles through the Locus CoeruleusNorepinephrine System. Nat. Chem. Biol. 2018, 14 (7), 655-663. https://doi.org/10.1038/s41589018-0062-z.

Halliwell, B.; Gutteridge, J. M. C. [1] Role of Free Radicals and Catalytic Metal lons in Human Disease: An Overview. In Methods in Enzymology; Oxygen Radicals in Biological Systems Part B: Oxygen Radicals and Antioxidants; Academic Press, 1990; Vol. 186, pp 1-85. https://doi.org/10.1016/0076-6879(90)86093-B.

Gaetke, L. M.; Chow, C. K. Copper Toxicity, Oxidative Stress, and Antioxidant Nutrients. Toxicology 2003, 189 (1), 147-163. https://doi.org/10.1016/S0300-483X(03)00159-8.

Brady, D. C.; Crowe, M. S.; Turski, M. L.; Hobbs, G. A.; Yao, X.; Chaikuad, A.; Knapp, S.; Xiao, K.; Campbell, S. L.; Thiele, D. J.; Counter, C. M. Copper Is Required for Oncogenic BRAF Signalling and Tumorigenesis. Nature 2014, 509 (7501), 492-496. https://doi.org/10.1038/nature13180.

Chung, C. Y.-S.; Posimo, J. M.; Lee, S.; Tsang, T.; Davis, J. M.; Brady, D. C.; Chang, C. J. ActivityBased Ratiometric FRET Probe Reveals Oncogene-Driven Changes in Labile Copper Pools Induced by Altered Glutathione Metabolism. Proc. Natl. Acad. Sci. 2019, 116 (37), 18285-18294. https://doi.org/10.1073/pnas.1904610116.

Tsang, T.; Posimo, J. M.; Gudiel, A. A.; Cicchini, M.; Feldser, D. M.; Brady, D. C. Copper Is an Essential Regulator of the Autophagic Kinases ULK1/2 to Drive Lung Adenocarcinoma. bioRxiv 2019, 816587. https://doi.org/10.1101/816587.

Fox, J. H.; Kama, J. A.; Lieberman, G.; Chopra, R.; Dorsey, K.; Chopra, V.; Volitakis, I.; Cherny, R. A.; Bush, A. I.; Hersch, S. Mechanisms of Copper Ion Mediated Huntington's Disease Progression. PLOS ONE 2007, 2 (3), e334. https://doi.org/10.1371/journal.pone.0000334.

Desai, V.; Kaler, S. G. Role of Copper in Human Neurological Disorders. Am. J. Clin. Nutr. 2008, 88 (3), 855S-858S. https://doi.org/10.1093/ajcn/88.3.855S.

Xiao, G.; Fan, Q.; Wang, X.; Zhou, B. Huntington Disease Arises from a Combinatory Toxicity of Polyglutamine and Copper Binding. Proc. Natl. Acad. Sci. 2013, 110 (37), 14995-15000. https://doi.org/10.1073/pnas.1308535110.

Hare, D. J.; New, E. J.; de Jonge, M. D.; McColl, G. Imaging Metals in Biology: Balancing Sensitivity, Selectivity and Spatial Resolution. Chem. Soc. Rev. 2015, 44 (17), 5941-5958. https://doi.org/10.1039/C5CS00055F.

Savelieff, M. G.; Nam, G.; Kang, J.; Lee, H. J.; Lee, M.; Lim, M. H. Development of Multifunctional Molecules as Potential Therapeutic Candidates for Alzheimer's Disease, Parkinson's Disease, and Amyotrophic Lateral Sclerosis in the Last Decade. Chem. Rev. 2019, 119 (2), 1221-1322. https://doi.org/10.1021/acs.chemrev.8b00138.

Barnes, N.; Tsivkovskii, R.; Tsivkovskaia, N.; Lutsenko, S. The Copper-Transporting ATPases, Menkes and Wilson Disease Proteins, Have Distinct Roles in Adult and Developing Cerebellum. J. Biol. Chem. 2005, 280 (10), 9640-9645. https://doi.org/10.1074/jbc.M413840200.

Kaler, S. G. ATP7A-Related Copper Transport Diseases-Emerging Concepts and Future Trends. Nat. Rev. Neurol. 2011, 7 (1), 15-29. https://doi.org/10.1038/nrneurol.2010.180.

Fieten, H.; Gill, Y.; Martin, A. J.; Concilli, M.; Dirksen, K.; Steenbeek, F. G. van; Spee, B.; Ingh, T. S. G. A. M. van den; Martens, E. C. C. P.; Festa, P.; Chesi, G.; Sluis, B. van de; Houwen, R. H. J. H.; Watson, A. L.; Aulchenko, Y. S.; Hodgkinson, V. L.; Zhu, S.; Petris, M. J.; Polishchuk, R. S.; Leegwater, P. A. J.; Rothuizen, J. The Menkes and Wilson Disease Genes Counteract in Copper Toxicosis in Labrador Retrievers: A New Canine Model for Copper-Metabolism Disorders. Dis. Model. Mech. 2016, 9 (1), 25-38. https://doi.org/10.1242/dmm.020263.

Jia, S.; Ramos-Torres, K. M.; Kolemen, S.; Ackerman, C. M.; Chang, C. J. Tuning the Color Palette of Fluorescent Copper Sensors through Systematic Heteroatom Substitution at Rhodol Cores. ACS Chem. Biol. 2017. https://doi.org/10.1021/acschembio.7b00748. 
(29) Domaille, D. W.; Que, E. L.; Chang, C. J. Synthetic Fluorescent Sensors for Studying the Cell Biology of Metals. Nat. Chem. Biol. 2008, 4 (3), 168-175. https://doi.org/10.1038/nchembio.69.

(30) Aron, A. T.; Ramos-Torres, K. M.; Cotruvo, J. A.; Chang, C. J. Recognition- and Reactivity-Based Fluorescent Probes for Studying Transition Metal Signaling in Living Systems. Acc. Chem. Res. 2015, 48 (8), 2434-2442. https://doi.org/10.1021/acs.accounts.5b00221.

(31) Carter, K. P.; Young, A. M.; Palmer, A. E. Fluorescent Sensors for Measuring Metal lons in Living Systems. Chem. Rev. 2014, 114 (8), 4564-4601. https://doi.org/10.1021/cr400546e.

(32) Zeng, L.; Miller, E. W.; Pralle, A.; Isacoff, E. Y.; Chang, C. J. A Selective Turn-On Fluorescent Sensor for Imaging Copper in Living Cells. J. Am. Chem. Soc. 2006, 128 (1), 10-11. https://doi.org/10.1021/ja055064u.

(33) Joseph A. Cotruvo, J.; Aron, A. T.; Ramos-Torres, K. M.; Chang, C. J. Synthetic Fluorescent Probes for Studying Copper in Biological Systems. Chem. Soc. Rev. 2015, 44 (13), 4400-4414. https://doi.org/10.1039/C4CS00346B.

(34) Ackerman, C. M.; Lee, S.; Chang, C. J. Analytical Methods for Imaging Metals in Biology: From Transition Metal Metabolism to Transition Metal Signaling. Anal. Chem. 2017, 89 (1), 22-41. https://doi.org/10.1021/acs.analchem.6b04631.

(35) Iovan, D. A.; Jia, S.; Chang, C. J. Inorganic Chemistry Approaches to Activity-Based Sensing: From Metal Sensors to Bioorthogonal Metal Chemistry. Inorg. Chem. 2019, 58 (20), 13546-13560. https://doi.org/10.1021/acs.inorgchem.9b01221.

(36) Fahrni, C. J. Synthetic Fluorescent Probes for Monovalent Copper. Curr. Opin. Chem. Biol. 2013, 17 (4), 656-662. https://doi.org/10.1016/j.cbpa.2013.05.019.

(37) Yang, L.; McRae, R.; Henary, M. M.; Patel, R.; Lai, B.; Vogt, S.; Fahrni, C. J. Imaging of the Intracellular Topography of Copper with a Fluorescent Sensor and by Synchrotron X-Ray Fluorescence Microscopy. Proc. Natl. Acad. Sci. 2005, 102 (32), 11179-11184. https://doi.org/10.1073/pnas.0406547102.

(38) Lin, W.; Yuan, L.; Tan, W.; Feng, J.; Long, L. Construction of Fluorescent Probes Via Protection/Deprotection of Functional Groups: A Ratiometric Fluorescent Probe for Cu2+. Chem. - Eur. J. 2009, 15 (4), 1030-1035. https://doi.org/10.1002/chem.200801501.

(39) Zhou, Y.; Wang, F.; Kim, Y.; Kim, S.-J.; Yoon, J. Cu2+-Selective Ratiometric and "Off-On" Sensor Based on the Rhodamine Derivative Bearing Pyrene Group. Org. Lett. 2009, 11 (19), 4442-4445. https://doi.org/10.1021/ol901804n.

(40) Taki, M.; lyoshi, S.; Ojida, A.; Hamachi, I.; Yamamoto, Y. Development of Highly Sensitive Fluorescent Probes for Detection of Intracellular Copper(I) in Living Systems. J. Am. Chem. Soc. 2010, 132 (17), 5938-5939. https://doi.org/10.1021/ja100714p.

(41) Domaille, D. W.; Zeng, L.; Chang, C. J. Visualizing Ascorbate-Triggered Release of Labile Copper within Living Cells Using a Ratiometric Fluorescent Sensor. J. Am. Chem. Soc. 2010, 132 (4), 1194-1195. https://doi.org/10.1021/ja907778b.

(42) Dodani, S. C.; Leary, S. C.; Cobine, P. A.; Winge, D. R.; Chang, C. J. A Targetable Fluorescent Sensor Reveals That Copper-Deficient SCO1 and SCO2 Patient Cells Prioritize Mitochondrial Copper Homeostasis. J. Am. Chem. Soc. 2011, 133 (22), 8606-8616. https://doi.org/10.1021/ja2004158.

(43) Hirayama, T.; Bittner, G. C. V. de; Gray, L. W.; Lutsenko, S.; Chang, C. J. Near-Infrared Fluorescent Sensor for in Vivo Copper Imaging in a Murine Wilson Disease Model. Proc. Natl. Acad. Sci. 2012, 109 (7), 2228-2233. https://doi.org/10.1073/pnas.1113729109.

(44) Shen, C.; Kolanowski, J. L.; Tran, C. M.-N.; Kaur, A.; Akerfeldt, M. C.; Rahme, M. S.; Hambley, T. W.; New, E. J. A Ratiometric Fluorescent Sensor for the Mitochondrial Copper Pool. Metallomics 2016, 8 (9), 915-919. https://doi.org/10.1039/C6MT00083E.

(45) Park, S. Y.; Kim, W.; Park, S.-H.; Han, J.; Lee, J.; Kang, C.; Lee, M. H. An Endoplasmic ReticulumSelective Ratiometric Fluorescent Probe for Imaging a Copper Pool. Chem. Commun. 2017, 53 (32), 4457-4460. https://doi.org/10.1039/C7CC01430A.

(46) Giuffrida, M. L.; Trusso Sfrazzetto, G.; Satriano, C.; Zimbone, S.; Tomaselli, G. A.; Copani, A.; Rizzarelli, E. A New Ratiometric Lysosomal Copper(II) Fluorescent Probe To Map a Dynamic Metallome in Live Cells. Inorg. Chem. 2018, 57 (5), 2365-2368. https://doi.org/10.1021/acs.inorgchem.7b02720.

(47) Morgan, M. T.; Bourassa, D.; Harankhedkar, S.; McCallum, A. M.; Zlatic, S. A.; Calvo, J. S.; Meloni, G.; Faundez, V.; Fahrni, C. J. Ratiometric Two-Photon Microscopy Reveals Attomolar Copper 
Buffering in Normal and Menkes Mutant Cells. Proc. Natl. Acad. Sci. 2019, 116 (25), 12167-12172. https://doi.org/10.1073/pnas.1900172116.

(48) Que, E. L.; Chang, C. J. Responsive Magnetic Resonance Imaging Contrast Agents as Chemical Sensors for Metals in Biology and Medicine. Chem. Soc. Rev. 2009, 39 (1), 51-60. https://doi.org/10.1039/B914348N.

(49) Pierre, V. C.; Harris, S. M.; Pailloux, S. L. Comparing Strategies in the Design of Responsive Contrast Agents for Magnetic Resonance Imaging: A Case Study with Copper and Zinc. Acc. Chem. Res. 2018, 51 (2), 342-351. https://doi.org/10.1021/acs.accounts.7b00301.

(50) Que, E. L.; Chang, C. J. A Smart Magnetic Resonance Contrast Agent for Selective Copper Sensing. J. Am. Chem. Soc. 2006, 128 (50), 15942-15943. https://doi.org/10.1021/ja065264l.

(51) Que, E. L.; Gianolio, E.; Baker, S. L.; Wong, A. P.; Aime, S.; Chang, C. J. Copper-Responsive Magnetic Resonance Imaging Contrast Agents. J. Am. Chem. Soc. 2009, 131 (24), 8527-8536. https://doi.org/10.1021/ja900884j.

(52) Que, E. L.; Gianolio, E.; Baker, S. L.; Aime, S.; Chang, C. J. A Copper-Activated Magnetic Resonance Imaging Contrast Agent with Improved Turn-on Relaxivity Response and Anion Compatibility. Dalton Trans. 2009, 39 (2), 469-476. https://doi.org/10.1039/B916931H.

(53) Que, E. L.; New, E. J.; Chang, C. J. A Cell-Permeable Gadolinium Contrast Agent for Magnetic Resonance Imaging of Copper in a Menkes Disease Model. Chem. Sci. 2012, 3 (6), 1829-1834. https://doi.org/10.1039/C2SC20273E.

(54) Smolensky, E. D.; Marjańska, M.; Pierre, V. C. A Responsive Particulate MRI Contrast Agent for Copper(I): A Cautionary Tale. Dalton Trans. 2012, 41 (26), 8039-8046. https://doi.org/10.1039/C2DT30416C.

(55) Weitz, E. A.; Lewandowski, C.; Smolensky, E. D.; Marjańska, M.; Pierre, V. C. A Magnetoplasmonic Imaging Agent for Copper(I) with Dual Response by MRI and Dark Field Microscopy. ACS Nano 2013, 7 (7), 5842-5849. https://doi.org/10.1021/nn400928z.

(56) Paranawithana, N. N.; Martins, A. F.; Clavijo Jordan, V.; Zhao, P.; Chirayil, S.; Meloni, G.; Sherry, A. D. A Responsive Magnetic Resonance Imaging Contrast Agent for Detection of Excess Copper(II) in the Liver In Vivo. J. Am. Chem. Soc. 2019, 141 (28), 11009-11018. https://doi.org/10.1021/jacs.8b13493.

(57) Heffern, M. C.; Park, H. M.; Au-Yeung, H. Y.; Bittner, G. C. V. de; Ackerman, C. M.; Stahl, A.; Chang, C. J. In Vivo Bioluminescence Imaging Reveals Copper Deficiency in a Murine Model of Nonalcoholic Fatty Liver Disease. Proc. Natl. Acad. Sci. 2016, 113 (50), 14219-14224. https://doi.org/10.1073/pnas.1613628113.

(58) Chang, C. J. Bioinorganic Life and Neural Activity: Toward a Chemistry of Consciousness? Acc. Chem. Res. 2017, 50 (3), 535-538. https://doi.org/10.1021/acs.accounts.6b00531.

(59) Krishnamoorthy, L.; Cotruvo Jr, J. A.; Chan, J.; Kaluarachchi, H.; Muchenditsi, A.; Pendyala, V. S.; Jia, S.; Aron, A. T.; Ackerman, C. M.; Wal, M. N. V.; Guan, T.; Smaga, L. P.; Farhi, S. L.; New, E. J.; Lutsenko, S.; Chang, C. J. Copper Regulates Cyclic-AMP-Dependent Lipolysis. Nat. Chem. Biol. 2016, 12 (8), 586-592. https://doi.org/10.1038/nchembio.2098.

(60) Maity, D.; Kumar, V.; Govindaraju, T. Reactive Probes for Ratiometric Detection of Co2+ and Cu+ Based on Excited-State Intramolecular Proton Transfer Mechanism. Org. Lett. 2012, 14 (23), 6008-6011. https://doi.org/10.1021/ol302904c.

(61) Taki, M.; Akaoka, K.; Mitsui, K.; Yamamoto, Y. A Mitochondria-Targeted Turn-on Fluorescent Probe Based on a Rhodol Platform for the Detection of Copper(I). Org. Biomol. Chem. 2014, 12 (27), 4999-5005. https://doi.org/10.1039/C4OB00527A.

(62) Maity, D.; Raj, A.; Karthigeyan, D.; Kundu, T. K.; Govindaraju, T. A Switch-on near-Infrared Fluorescence-Ready Probe for Cu(I): Live Cell Imaging. Supramol. Chem. 2015, 27 (9), 589-594. https://doi.org/10.1080/10610278.2015.1041953.

(63) Hu, Z.; Hu, J.; Wang, H.; Zhang, Q.; Zhao, M.; Brommesson, C.; Tian, Y.; Gao, H.; Zhang, X.; Uvdal, K. A TPA-Caged Precursor of (Imino)Coumarin for "Turn-on" Fluorogenic Detection of Cu+. Anal. Chim. Acta 2016, 933, 189-195. https://doi.org/10.1016/j.aca.2016.05.031.

(64) Chan, J.; Dodani, S. C.; Chang, C. J. Reaction-Based Small-Molecule Fluorescent Probes for Chemoselective Bioimaging. Nat. Chem. 2012, 4 (12), 973-984. https://doi.org/10.1038/nchem.1500. 
(65) Bruemmer, K. J.; Crossley, S. W. M.; Chang, C. J. Activity-Based Sensing: A Synthetic Methods Approach for Selective Molecular Imaging and Beyond. Angew. Chem. Int. Ed. n/a (n/a). https://doi.org/10.1002/anie.201909690.

(66) Fujishima, S.; Yasui, R.; Miki, T.; Ojida, A.; Hamachi, I. Ligand-Directed Acyl Imidazole Chemistry for Labeling of Membrane-Bound Proteins on Live Cells. J. Am. Chem. Soc. 2012, 134 (9), 39613964. https://doi.org/10.1021/ja2108855.

(67) Miki, T.; Awa, M.; Nishikawa, Y.; Kiyonaka, S.; Wakabayashi, M.; Ishihama, Y.; Hamachi, I. A Conditional Proteomics Approach to Identify Proteins Involved in Zinc Homeostasis. Nat. Methods 2016, 13 (11), 931-937. https://doi.org/10.1038/nmeth.3998.

(68) Matsuo, K.; Hamachi, I. Ligand-Directed Tosyl and Acyl Imidazole Chemistry. In Chemoselective and Bioorthogonal Ligation Reactions; Algar, W. R., Dawson, P. E., Medintz, I. L., Eds.; Wiley-VCH Verlag GmbH \& Co. KGaA, 2017; pp 147-163. https://doi.org/10.1002/9783527683451.ch6.

(69) Zhu, H.; Tamura, T.; Hamachi, I. Chemical Proteomics for Subcellular Proteome Analysis. Curr. Opin. Chem. Biol. 2019, 48, 1-7. https://doi.org/10.1016/j.cbpa.2018.08.001.

(70) Tamura, T.; Hamachi, I. Chemistry for Covalent Modification of Endogenous/Native Proteins: From Test Tubes to Complex Biological Systems. J. Am. Chem. Soc. 2019, 141 (7), 2782-2799. https://doi.org/10.1021/jacs.8b11747.

(71) Nishikawa, Y.; Miki, T.; Awa, M.; Kuwata, K.; Tamura, T.; Hamachi, I. Development of a Nitric Oxide-Responsive Labeling Reagent for Proteome Analysis of Live Cells. ACS Chem. Biol. 2019, 14 (3), 397-404. https://doi.org/10.1021/acschembio.8b01021.

(72) Sakamoto, S.; Hamachi, I. Recent Progress in Chemical Modification of Proteins. Anal. Sci. 2019, 35 (1), 5-27. https://doi.org/10.2116/analsci.18R003.

(73) Palmer, A. E.; Tsien, R. Y. Measuring Calcium Signaling Using Genetically Targetable Fluorescent Indicators. Nat. Protoc. 2006, 1 (3), 1057-1065. https://doi.org/10.1038/nprot.2006.172.

(74) Nolan, E. M.; Lippard, S. J. Small-Molecule Fluorescent Sensors for Investigating Zinc Metalloneurochemistry. Acc. Chem. Res. 2009, 42 (1), 193-203. https://doi.org/10.1021/ar8001409.

(75) Dean, K. M.; Qin, Y.; Palmer, A. E. Visualizing Metal lons in Cells: An Overview of Analytical Techniques, Approaches, and Probes. Biochim. Biophys. Acta BBA - Mol. Cell Res. 2012, 1823 (9), 1406-1415. https://doi.org/10.1016/j.bbamcr.2012.04.001.

(76) Miller, E. W.; Zeng, L.; Domaille, D. W.; Chang, C. J. Preparation and Use of Coppersensor-1, a Synthetic Fluorophore for Live-Cell Copper Imaging. Nat. Protoc. 2006, 1 (2), 824-827. https://doi.org/10.1038/nprot.2006.140.

(77) Hong-Hermesdorf, A.; Miethke, M.; Gallaher, S. D.; Kropat, J.; Dodani, S. C.; Chan, J.; Barupala, D.; Domaille, D. W.; Shirasaki, D. I.; Loo, J. A.; Weber, P. K.; Pett-Ridge, J.; Stemmler, T. L.; Chang, C. J.; Merchant, S. S. Subcellular Metal Imaging Identifies Dynamic Sites of Cu Accumulation in Chlamydomonas. Nat. Chem. Biol. 2014, 10 (12), 1034-1042. https://doi.org/10.1038/nchembio.1662.

(78) Lee, S.; Barin, G.; Ackerman, C. M.; Muchenditsi, A.; Xu, J.; Reimer, J. A.; Lutsenko, S.; Long, J. R.; Chang, C. J. Copper Capture in a Thioether-Functionalized Porous Polymer Applied to the Detection of Wilson's Disease. J. Am. Chem. Soc. 2016, 138 (24), 7603-7609. https://doi.org/10.1021/jacs.6b02515.

(79) Lukinavičius, G.; Umezawa, K.; Olivier, N.; Honigmann, A.; Yang, G.; Plass, T.; Mueller, V.; Reymond, L.; Jr, I. R. C.; Luo, Z.-G.; Schultz, C.; Lemke, E. A.; Heppenstall, P.; Eggeling, C.; Manley, S.; Johnsson, K. A Near-Infrared Fluorophore for Live-Cell Super-Resolution Microscopy of Cellular Proteins. Nat. Chem. 2013, 5 (2), 132. https://doi.org/10.1038/nchem.1546.

(80) Wagner, B. D. The Use of Coumarins as Environmentally-Sensitive Fluorescent Probes of Heterogeneous Inclusion Systems. Mol. 2009 210-237.

(81) Castner, E. W.; Kennedy, D.; Cave, R. J. Solvent as Electron Donor: Donor/Acceptor Electronic Coupling Is a Dynamical Variable. J. Phys. Chem. A 2000, 104 (13), 2869-2885. https://doi.org/10.1021/jp9936852.

(82) Petris, M. J.; Mercer, J. F.; Culvenor, J. G.; Lockhart, P.; Gleeson, P. A.; Camakaris, J. LigandRegulated Transport of the Menkes Copper P-Type ATPase Efflux Pump from the Golgi Apparatus to the Plasma Membrane: A Novel Mechanism of Regulated Trafficking. EMBO J. 1996, 15 (22), 6084-6095. https://doi.org/10.1002/j.1460-2075.1996.tb00997.x. 
(83) Camakaris, J.; Voskoboinik, I.; Mercer, J. F. Molecular Mechanisms of Copper Homeostasis. Biochem. Biophys. Res. Commun. 1999, 261 (2), 225-232. https://doi.org/10.1006/bbrc.1999.1073.

(84) Linz, R.; Lutsenko, S. Copper-Transporting ATPases ATP7A and ATP7B: Cousins, Not Twins. J. Bioenerg. Biomembr. 2007, 39 (5-6), 403-407. https://doi.org/10.1007/s10863-007-9101-2.

(85) Gupta, A.; Lutsenko, S. Human Copper Transporters: Mechanism, Role in Human Diseases and Therapeutic Potential. Future Med. Chem. 2009, 1 (6), 1125-1142. https://doi.org/10.4155/fmc.09.84.

(86) Lutsenko, S.; Bhattacharjee, A.; Hubbard, A. L. Copper Handling Machinery of the Brain. Metallomics 2010, 2 (9), 596-608. https://doi.org/10.1039/COMT00006J.

Gaier, E. D.; Eipper, B. A.; Mains, R. E. Copper Signaling in the Mammalian Nervous System: Synaptic Effects. J. Neurosci. Res. 2013, 91 (1), 2-19. https://doi.org/10.1002/jnr.23143.

Zimbrean, P. C.; Schilsky, M. L. Psychiatric Aspects of Wilson Disease: A Review. Gen. Hosp. Psychiatry 2014, 36 (1), 53-62. https://doi.org/10.1016/j.genhosppsych.2013.08.007.

Kardos, J.; Héja, L.; Simon, Á.; Jablonkai, I.; Kovács, R.; Jemnitz, K. Copper Signalling: Causes and Consequences. Cell Commun. Signal. 2018, 16 (1), 71. https://doi.org/10.1186/s12964-0180277-3.

Campbell, A. The Role of Aluminum and Copper on Neuroinflammation and Alzheimer's Disease. J. Alzheimers Dis. 2006, 10 (2/3), 165-172.

Choo, X. Y.; Alukaidey, L.; White, A. R.; Grubman, A. Neuroinflammation and Copper in Alzheimer's Disease https://www.hindawi.com/journals/ijad/2013/145345/ (accessed Dec 18, 2019). https://doi.org/10.1155/2013/145345.

Dusek, P.; Roos, P. M.; Litwin, T.; Schneider, S. A.; Flaten, T. P.; Aaseth, J. The Neurotoxicity of Iron, Copper and Manganese in Parkinson's and Wilson's Diseases. J. Trace Elem. Med. Biol. 2015, 31, 193-203. https://doi.org/10.1016/j.jtemb.2014.05.007.

Bulcke, F.; Dringen, R.; Scheiber, I. F. Neurotoxicity of Copper. In Neurotoxicity of Metals; Aschner, M., Costa, L. G., Eds.; Advances in Neurobiology; Springer International Publishing: Cham, 2017; pp 313-343. https://doi.org/10.1007/978-3-319-60189-2_16.

Brosenitsch, T. A.; Katz, D. M. Physiological Patterns of Electrical Stimulation Can Induce Neuronal Gene Expression by Activating N-Type Calcium Channels. J. Neurosci. 2001, 21 (8), 2571-2579. https://doi.org/10.1523/JNEUROSCl.21-08-02571.2001.

Ghasemi-Mobarakeh, L.; Prabhakaran, M. P.; Morshed, M.; Nasr-Esfahani, M. H.; Baharvand, H.; Kiani, S.; Al-Deyab, S. S.; Ramakrishna, S. Application of Conductive Polymers, Scaffolds and Electrical Stimulation for Nerve Tissue Engineering. J. Tissue Eng. Regen. Med. 5 (4), e17-e35. https://doi.org/10.1002/term.383.

Reemst, K.; Noctor, S. C.; Lucassen, P. J.; Hol, E. M. The Indispensable Roles of Microglia and Astrocytes during Brain Development. Front. Hum. Neurosci. 2016, 10. https://doi.org/10.3389/fnhum.2016.00566.

Dringen, R.; Scheiber, I. F.; Mercer, J. F. B. Copper Metabolism of Astrocytes. Front. Aging Neurosci. 2013, 5. https://doi.org/10.3389/fnagi.2013.00009.

Saijo, K.; Crotti, A.; Glass, C. K. Regulation of Microglia Activation and Deactivation by Nuclear Receptors. Glia 2013, 61 (1), 104-111. https://doi.org/10.1002/glia.22423.

Chung, W.-S.; Allen, N. J.; Eroglu, C. Astrocytes Control Synapse Formation, Function, and Elimination. Cold Spring Harb. Perspect. Biol. 2015, 7 (9), a020370. https://doi.org/10.1101/cshperspect.a020370.

Niciu, M. J.; Ma, X.-M.; El Meskini, R.; Ronnett, G. V.; Mains, R. E.; Eipper, B. A. Developmental Changes in the Expression of ATP7A during a Critical Period in Postnatal Neurodevelopment. Neuroscience 2006, 139 (3), 947-964. https://doi.org/10.1016/j.neuroscience.2006.01.044.

Zheng, Z.; White, C.; Lee, J.; Peterson, T. S.; Bush, A. I.; Sun, G. Y.; Weisman, G. A.; Petris, M. J. Altered Microglial Copper Homeostasis in a Mouse Model of Alzheimer's Disease. J. Neurochem. 2010, 114 (6), 1630-1638. https://doi.org/10.1111/j.1471-4159.2010.06888.x.

Telianidis, J.; Hung, Y. H.; Materia, S.; La Fontaine, S. Role of the P-Type ATPases, ATP7A and ATP7B in Brain Copper Homeostasis. Front. Aging Neurosci. 2013, 5. https://doi.org/10.3389/fnagi.2013.00044. 